\title{
The Finnish Museums ASSOCIATION \\ - 75 YEARS WORKING FOR MUSEUMS
}

\author{
Janne Vilkuna
}

The Finnish Museums Association was founded in 1923. On the occasion of its 75th anniverssary last year, Janne Vilkuna recorded its history in "75 vuotta museoiden hyväksi" published by the Association. For the benefit of the readers of Nordisk Museologi Professor Vilkuna here gives a short resumé of his book.

\section{BEFORE THE ESTABLISHMENT OF THE ASSOCIATION}

In 1809, Finland, formerly part of Sweden, became an autonomous Grand Duchy within the Russian Empire. This provided the impetus for economic, administrative and cultural reforms that enabled the country to establish itself as a fully-fledged civilized nation. The seeds of the national awakening had already been sown in the Turku Academy, Finland's only university, but after being ravaged by fire in 1827, Turku lost both the university and its status as the nation's capital to Helsinki, which was in any case geographically closer to St Petersburg.

Helsinki, according to the university statutes of 1828, took over the role of the Turku Academy as host to a number of collections. The University was to have botanical gardens, a museum of natural history, and cabinets for minerals, coins, medals and art. The first 'rural', i.e. local history, museums outside the capital were established between the 1860s and 1890s. Actually, these museums sprang up so rapidly that, by the turn of the century, a third of all Finnish cities and towns could boast a museum.

A decree concerning archaeological remains was issued in 1883 and the following year, the National Board of Antiquities (NBA), headed by a State Archaeologist, was established to supervise its implementation. The first steps in the process that led to the establishment of the National Museum of Finland were taken in 1893, when a number of museums and collections in Helsinki were put together to form the State Historical Museum under the NBA. The collections were moved to a new building in 1910 and opened to the public on January 31, 
JANNE VILKUnA

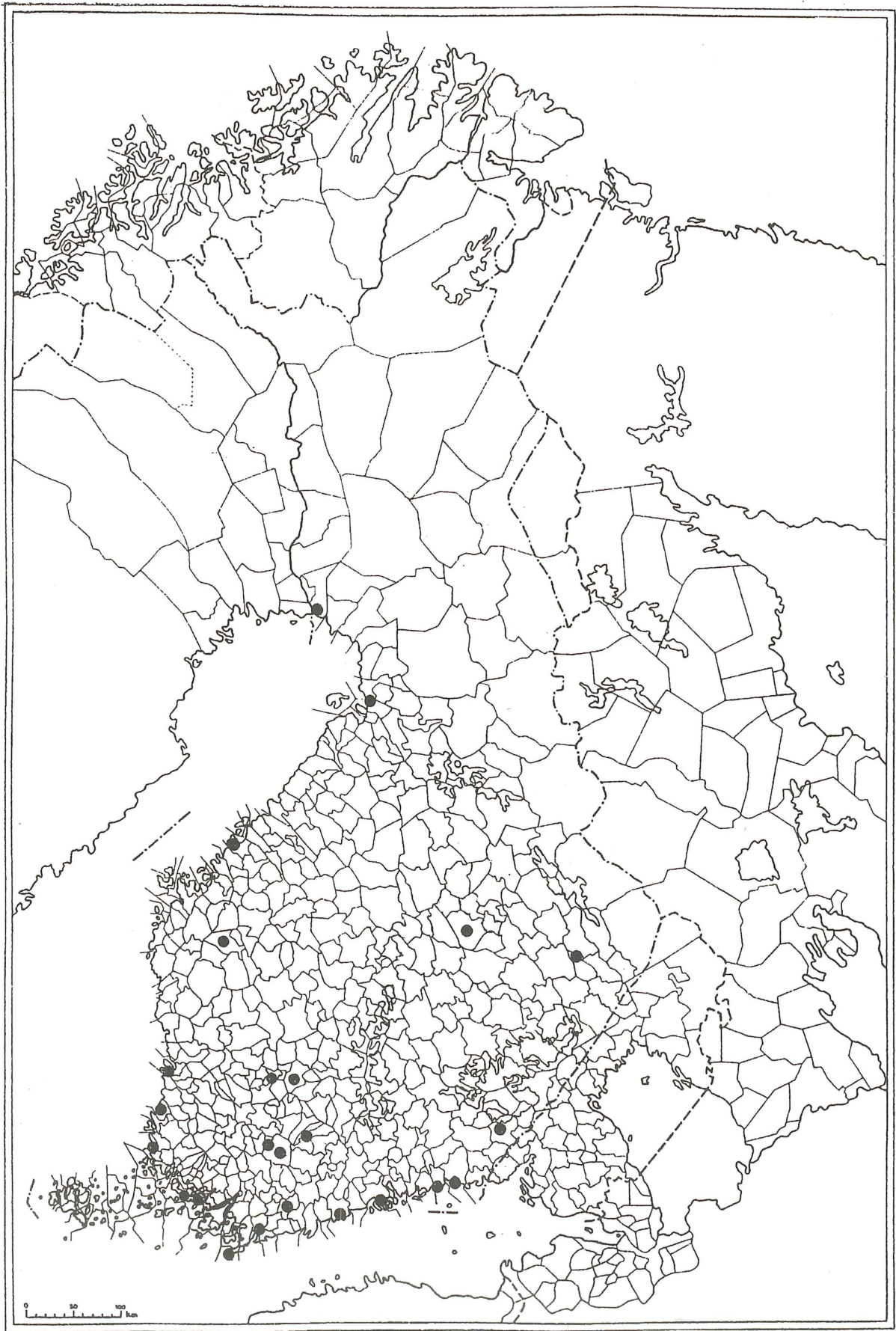


1916. The NBA was a statutory authority with no advisory function.

The second conference on Finnish local culture and heritage held in Helsinki in 1909 discussed the question of local museums and appointed a museum committee. In proposing the establishment of an organization that would provide a framework for better cooperation between museums, the committee was inspired by the Swedish Museums Association set up in 1906. The committee also proposed the appointment of a museum inspector working at the National Museum, the publication of a handbook and the provision of training for museum employees. However, none of these proposals was implemented, possibly because they might have put the whole National Museum project in jeopardy.

In 1917, when Finland gained its independence, the nation had 25 museums (excluding State museums), six of which were in rural districts. The NBA employed 12 officials, but most local museums were run by part-time curators with modest annual salaries. (There was only one official post in a museum outside Helsinki.) The three art museum officials who existed worked at the Art Museum of the Ateneum (now the Finnish National Gallery) in Helsinki, and there were 11 officials working in the field of natural history, all employed by the University of Helsinki.

As the 1920s dawned, the Scandinavian Museums Association provided Finns in search of a cooperative museums organization with another inspiration, in addition to the already-mentioned Swedish Muse- ums Association and its proposed Finnish equivalent. The Scandinavian organization had been established in 1915 and Finns joined it in 1921.

\section{THE ASSOCIATION IS ESTABLISHED}

The 40th anniversary meeting of the Governing Board of the Turku Historical Museum held at Turku Castle in September 1921 adopted Julius Finnberg's initiative concerning cooperation between local museums. In June 1922, Finnberg sent a letter to the NBA asking it to take measures that would enable local museums to cooperate; one of his suggestions was a NBA-sponsored meeting of museum representatives in Helsinki. Times had certainly changed since 1909: Hjalmar Appelgren-Kivalo, the State Archaeologist, was very supportive and consequently, the NBA appointed a preparatory committee with Julius Ailio (18721933), head of its Prehistory Section, as chairman and Julius Finnberg as secretary. Ailio, son of a primary school teacher and a Social Democratic Member of Parliament, had the cause of popular education very much at heart and believed that it would be furthered by museums. He was therefore an enthusiastic proponent of cooperation between local museums and later on played an important role in the establishment of the Finnish Museums Association. His action was in keeping with the spirit of the times: Finland had just become an independent republic, and economic and cultural progress and social equality were regarded as fundamental to the country's future. 
20 The first Museum Symposium convened by the NBA was held at the National Museum in January 1923. The two-day event was attended by 52 representatives from 39 Finnish museums, who listened to lectures on museum-related topics and introduced three subjects for discussion, two of them concerning the establishment of a central organization for Finnish museums. An interim governing board headed by Ailio was appointed to prepare the process. A grant from the Ministry of Education enabled the topics covered by the Symposium to be published as a book, but efforts to gain parliamentary approval for local museum grants failed.

Once the interim governing board had drawn up the proposed rules of the new central organization, the museums represented at the January Symposium were invited to the constitutive meeting. Representatives of ten museums were present on Sunday, September 30, 1923, at the National Museum of Finland when the new central organization of Finnish museums was established and its rules were approved. According to the rules, only 'an association in Finland that owns a cultural history museum or a board legally representing such a museum can join the organization'. Despite this provision, the name 'Association of Finnish Cultural History Museums' was rejected, instead the 'Finnish Museums Association' was adopted. This kept the door open for other museums to join. After all, those attending the constitutive meeting were also familiar with both art and natural history museums.

The founding process, the place of the constitutive meeting and the fact that Ailio, an NBA official, was elected the first Chairman, showed that the Association had close links with both the NBA and the National Museum of Finland. However, the clearest indication of the connection was the membership requirement and the fact that, according to the rules, the Association was to focus on cultural history.

The rules laid down that the Finnish Museums Association was to function as a 'link between cultural history museums, museum associations and museum officials and enthusiasts, and to promote their activities and interests'. The aim was to protect, collect and preserve cultural documents and to carry out cultural research. All this was to be achieved through training and advisory services. Financial assistance to museums was also mentioned as a possible form of activity. Membership was divided into three categories: corporate membership, contributing membership and honorary membership.

By the 1924 Annual Meeting, a total of 24 museums or associations owning a museum had registered as corporate members. However, efforts to attract contributing members were not as successful: 19 of the first 28 contributing members came from the National Museum or the Helsinki City Museum. Moreover, the membership fees the Association managed to collect during this initial period were insufficient to implement the aims envisaged in the rules.

\section{YEARS OF PEACE - 1924-1938}

The rules decreed that the Association's Annual Meeting should elect the members and deputy members of the Governing Board for a three-year period. It was also 


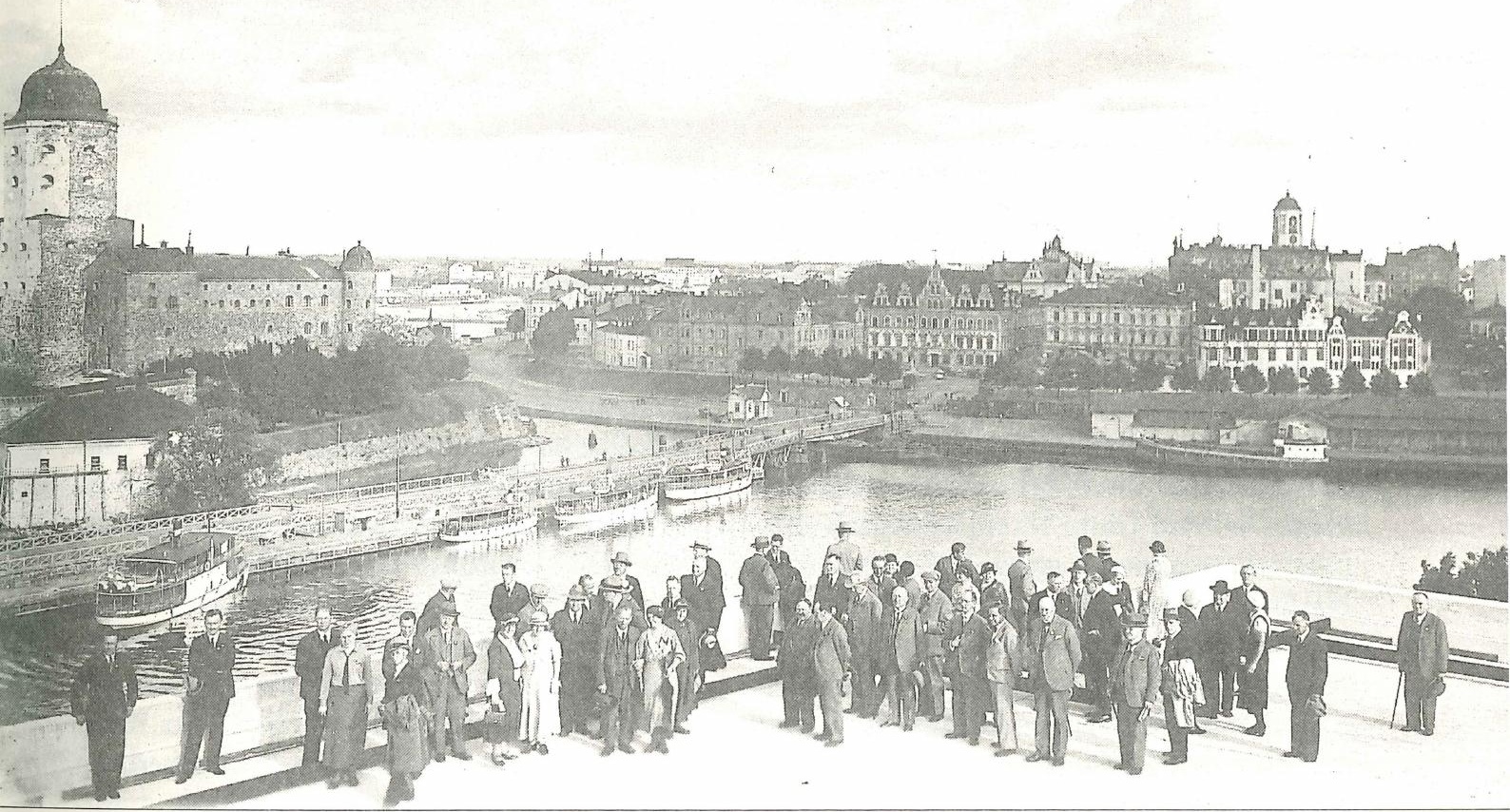

Museum Symposium was held in Viborg in 1934. Participants visited the new art museum planned by architect Uno Ullberg and the old medieval castle.

stipulated that 'the five-member Board should elect the Chairman and the Deputy Chairman from among themselves and also appoint the other officials and any aides needed'.

Through the Governing Board, the Chairman and the Secretary played a central role in the Finnish Museums Association in the pre-war period, the Board members, coming from the NBA, were also active, e.g. in providing local museums with advice. In the '20s and '30s, the provision of advice was mainly the responsibility of NBA officials, whose travel expenses were reimbursed by the Association. In the 1930s, the Association also began to provide museums with financial assistance for carrying out specific work, such as setting up exhibitions, and recommended an expert for each job. As travel was slow and expensive, the members of the Governing Board came from a fairly restricted geographical area. Thus, the Annual Meetings held in connection with the Museum Symposiums and attended by corporate members were the most important gatherings of the Association. The Symposiums were held in different parts of Finland in specific years (1926, 1930, 1934, 1938) and, in keeping with the practice adopted at the very first Symposium, the topics discussed and decisions made were published. The first museum directory was published in 1932 .

As the Finnish Museums Association was an auxiliary organization of the NBA at the National Museum of Finland, its main task was to improve the standards at local museums. From 1927 onwards, the Association could focus on this field in earnest, as it was able to use the proceeds from the State lottery to assist local 
22 museums and train their curators. The first three training courses for museum curators were held at the National Museum in 1928, 1929 and 1930. The Association also provided museums with grants from the money it received from the State, and from the 1950s onwards, it also acted as an NBA advisor when the NBA handed out State subsidies. This practice continued until 1974, when the NBA became solely responsible for the process. In 1937, the Association was allowed to participate in organizing the lucrative cultural lottery, enabling scholarships to be awarded from the Association's own funds.

During the Second World War, the Finnish Museums Association had to operate under exceptional circumstances, for during the period starting with the Soviet invasion in late 1939 and ending in spring 1945, the war effort dominated all aspects of life. However, the Association still received State grants to hand out to museums and was involved in the evacuation and safekeeping of museum collections, both in the war zone and elsewhere in the country. Despite the war, the fourth training course for museum curators was held in 1942. The Association also suffered losses: Esa Kahila, its energetic Secretary and a promising museum specialist and scientist, was killed in early March 1940.

\section{A MUSEUM ADVISER WORKING AT HOME AND AT THE NATIONAL MUSEUM - 1946-1956}

In the immediate post-war period, the life of Finland's four million people was characterized by the need to resettle 500,000 displaced persons and former soldiers, the reconstruction effort, war reparations to the Soviet Union totalling 300 million dollars, and rationing. However, the 1952 Helsinki Olympic Games showed that Finland had left the years of material austerity behind and had regained its status as a fully-fledged member of the international community.

The pressures of the war years and the lost traditions and way of life in the areas ceded to the Soviet Union as a result of the conflict were conducive to an atmosphere with strong local, provincial and national identities. Thus, like the other Nordic countries, Finland embarked on updating its legislation on cultural monuments. In a 1950 report, a committee appointed three years earlier proposed a revision of the laws protecting ancient monuments and culturally significant buildings, and new laws to prevent the export of cultural property. However, no bills to this end were submitted to Parliament until the 1960s.

In 1947, the NBA took up the idea of a partially decentralized antiquities administration. The proposal, first put forward before the war, envisaged a regional organization in which provincial museums would be headed by provincial archaeologists. The plan failed to materialize, but some progress was nevertheless made at the other end of the museum hierarchy.

In the post-war period of transition, the nation's cultural heritage assumed great importance, a fact indicated by the establishment of the Finnish Association for Local Culture and Heritage in 1949. Many of the local organizations set up also made the establishment of a local museum of culture and heritage their primary aim, and as a result, nearly every 
Finnish district had a museum by the 1950s.

After the war, an increasing number of museums outside Helsinki were able to employ full-time officials. An Association survey made much later (1991) of the age and education levels of museum employees revealed that three of the 607 respondents had entered the sector as early as 19501955 and eight in 1956-1960. The idea of museum professionals thus started to gain wider acceptance, though limited financial resources and engrained local attitudes were still a problem.

One manifestation of the efforts being made to strengthen national identity and provide museums with the necessary tools was the Parliamentary decision to grant the Association funds enabling it to add a museum adviser to its staff in 1946. The motivation for the decision was the argument that 'so far, museums have failed to make an appropriate contribution to Finnish cultural life', and that 'in addition to the public at large, they should cater for certain specific groups such as schools'. The adviser (who also acted as the Governing Board's Secretary) could cover almost 30 museums in one hundred days of travel, i.e. the Association was able to double the number of museums provided with professional advice. Moreover, it was once again possible to organize a lottery; the resulting generous proceeds of which enabled the Association to launch the glossy Osma yearbook in 1955, replacing the drab Museoliitto-Museiförbundet (Museums Association) quarterly published in 19451955.
THE ASSOCIATION ON

THE WAY TO INDEPENDENCE 1957-1974

The period 1957-1974 was a time of rising prosperity in Finland. Both the state and the local authorities saw their tax revenues increasing, and this, together with the principle of social justice inspired by Sweden, led to improvements in social and cultural services. Higher levels of education - the result of concerted state efforts, especially from the 1960s onwards - put pressure on cultural institutions. As more people gained a university education, a large number of graduates with MA and BA degrees started to enter the museum profession.

Acting in accordance with the 1950 committee report, Parliament approved the Protection of Antiquities Act and an act to protect culturally important buildings in 1963 and 1964, respectively. However, legislation restricting the export of cultural property failed to materialize. The 1970 proposals made by a government-appointed committee concerning the reorganization of the NBA were implemented in 1972, but the same committee's proposal for a regional museum administration with provincial antiquarians was not realized. The committee also proposed the creation of a statutory system of state subsidies for improving the finances of cultural history museums run by local authorities and private bodies.

In the 1970s, the state began to show a keen interest in museums and three bodies were appointed in 1972 to deal with related matters. The proposed act on state subsidies for provincial cultural history museums, art museums and national spe- 
24 cialized museums was the most important result of their deliberations.

In the '60s and '70s, professionalization gained ground in the museum field as part-time curators were rapidly replaced by full-time museum directors. Of the 607 respondents in the Association's 1991 survey, 29 had entered the field in 19611965, 53 in 1966-1970 and 113 in 19711975. During the initial stages of this professionalization, in the 1960s, the Association was still providing museum employees with the same training as they had given during the war. Though individuals could also join the Association, it was felt that activities of a more distinctive character were needed. The Swedish section of the Nordic Association of Restorers was set up in 1950, leading to the establishment of similar sections in other countries. Finnish restorers followed the example set by their Nordic colleagues in 1963, and six years later, the Finnish Trade Union of Museum Employees was established.

As the Finnish Museums Association expanded to cover new fields and the number of its permanent staff grew to five, it was transformed from an NBA auxiliary body into an organization for all Finnish museums. The Finnish Museums Association adhered to this principle throughout the 1960s, even though both it and the museums were affected by the growing politicization of the period. The revised rules of 1967 reflected the gradual changes in the Association's operational approach and stated that it now represen-

Participants of the Museum Symposium held in Hamina in 1968. ted all Finnish museums, not only those dealing with cultural history.

Inspired by the 1961 Library Act and its state subsidy principles, the Association's museum law committee proposed in 1965 that a hierarchical national network of museums should be established and that state subsidies for museums should be introduced. The Association also encouraged museums to employ officials on a permanent basis and tried to supervise their qualification requirements.

Lack of funds led to the discontinuation of the Osma yearbook in 1964. The money, however, was spent on other projects, such as the textile laboratory set up in 1963 to restore the textile collections of the museums that were Association mem-

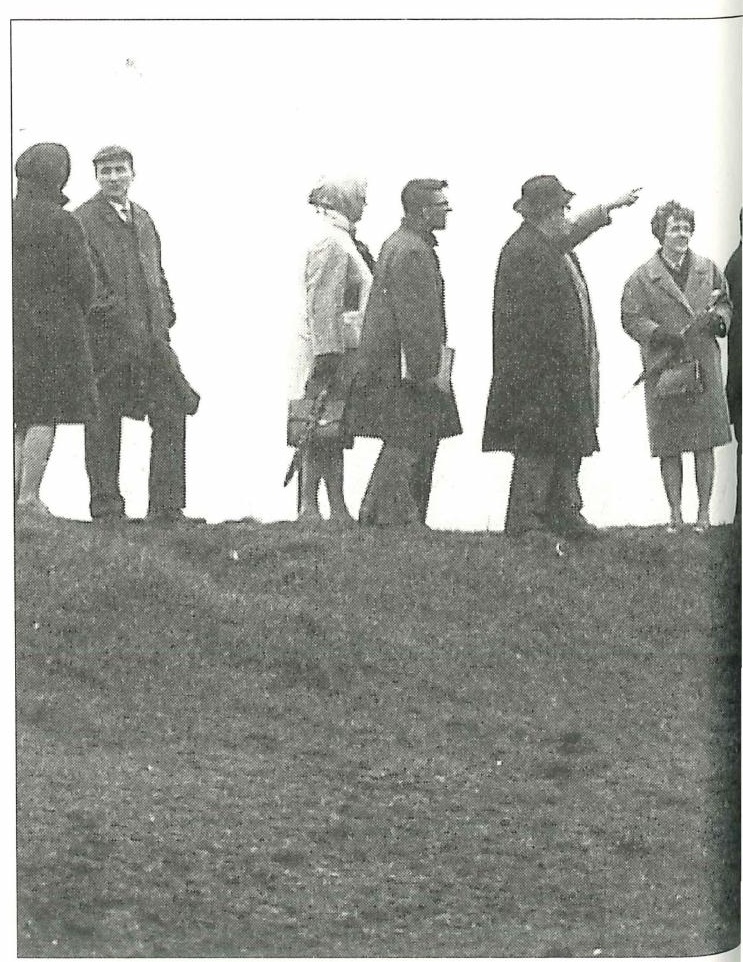


bers. The restorer working in the laboratory also provided people in the field with training and advice and brought out related publications. The original targets were eventually met and the laboratory was closed down in 1990. After the discontinuation of Osma, the Association did not have a regular publication until 1971, when an Information Officer joined its staff and the first issue of the journal Suomen Museoliitto tiedottad was brought out. The publication's name was changed to Museo (Museum) in 1984.

In 1966, the Finnish Museums Association was commissioned by the Government to prepare an exhibition which would tour Finland in connection with the country's 50th anniversary of inde- pendence in 1967. The exhibition Suomen tie (Finland's Way) was shown in eight museums and seen by almost 110,000 people. The next touring exhibition, Cilgetus saamelaiskulttuurin murros (Gilgetus, the Sámi culture in transition) toured Finland and other countries in 19731981. Though this kind of activity had got off to a good start, it had to be discontinued as no further funds were made available. A permanent organization for touring exhibitions thus never materialized.

The directory of the museums that were Association members was expanded in 1969 to cover all Finnish museums. The first English version was published in 1973.
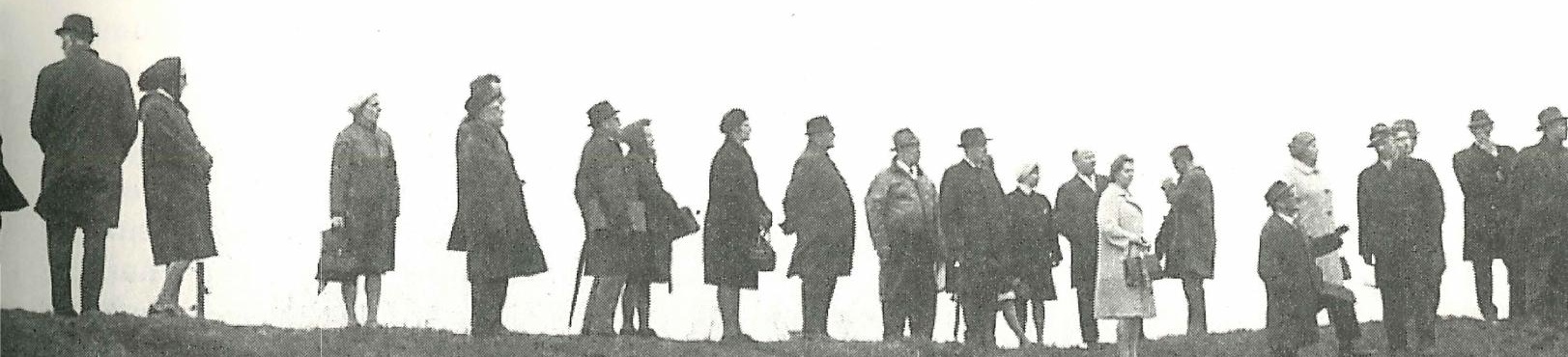
26 Although the Finnish Museums Association had already established links with other Nordic countries before the war, the 1950s heralded a new phase in its international contacts as the Association started to be active within the International Council of Museums (ICOM). Since then, ideas and models provided by colleagues in other countries have often proved very useful.

\section{A TIME OF CHANGE - 1975-1998}

The 1974 oil crisis, though demonstrating that a continuous rise in the standard of living could not be taken for granted, passed over and was eventually forgotten. Partly unsustainable economic growth then continued until late 1991, when the Finnish economy collapsed and unemployment reached unprecedented levels. The ensuing recession and efforts to cut the public debt forced the state and local authorities to reduce their services.

At the same time, Finland began a political and economic rapprochement with the rest of Europe and eventually joined the European Union in 1995. It now had to harmonize its legislation, administration and economy with EU directives and principles.

The Protection of Antiquities Act and the act to protect culturally important buildings entered the statute books in the early 1960s, but the Act on Restrictions on the Export of Cultural Property did not become a reality until 1978 . It has remained in force since Finland joined the EU.

Even though the three attempts to revise the Protection of Antiquities Act (1979, 1984 and 1993) proved unsuccessful, the Act and Decree concerning the Protection of Buildings came into effect in 1985 and 1988 , respectively. The proposal to legislate for state subsidies to provincial cultural history museums and national specialized museums put forward in the report of the committee on the regional museum administration in 1973 did not lead to any direct changes in the law. However the 1979 Government decision on state subsidies for museums created a national system of regional museums comprising provincial cultural history museums and regional art museums. In 1998 these totalled $36(20+16)$, but there was still no system of regional natural history museums.

As proposed by the working groups of the Ministry of Education in 1980 and 1983, the act and decree concerning state subsidies for museums were finally passed in 1988 and 1989, respectively. The system covered both provincial cultural history museums and regional art museums, but other museums could also receive discretionary subsidies.

The 1992 decree concerning the reorganization of the NBA named the National Museum of Finland the National Central Museum of Cultural History. The Finnish National Gallery had already been named the Central Museum of Visual Arts in 1990, and the Helsinki University Museum of Natural History became the Finnish Museum of Natural History in 1991.

After only a few years, in 1992, the act and decree concerning state subsidies were replaced with a new Museums Act and 


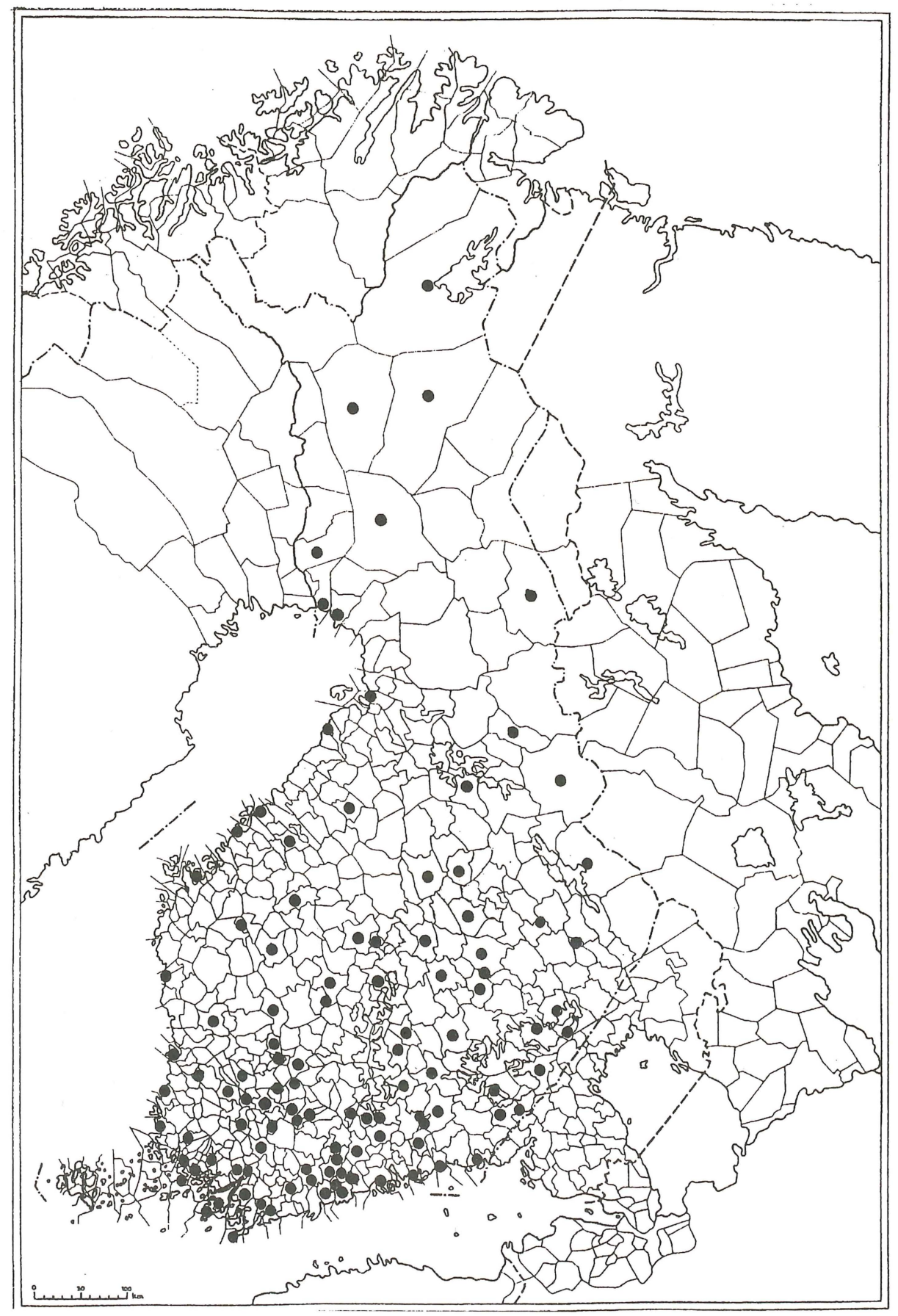


28 Decree. As the new provisions apply to all (non-governmental) museums with permanent employees, the number of museums eligible for state subsidies tripled. The national specialized museums, covered by a Ministry of Education memorandum in 1985, had already been included in the provisions of 1988 and 1989. However, the naming of the first specialized museums had to wait until 1993, i.e. after the 1992 act and decree came into force. In 1998 there were 12 such museums. The naming of the national specialized museums also finalized the nationwide museum network. It now comprises central museums, specialized museums, provincial museums and regional art museums (51 in all; the rest, totalling more than 950, are considered local museums irrespective of their operational resources).

The welfare state ideal led to the creation of a bloated bureaucracy that the country could not afford. Following the recession in the early 1990s, the state and local authorities had to balance their books by cutting expenditure. However, because the 1992 Museums Act required state subsidies to be calculated using person work-years, no museums were closed or permanent museum staff made redundant. Nevertheless, services were cut back, as local authorities provided the museums with less money to cover their running costs.

The new Museums Act initially included no provisions concerning the important role of museums in society. However, an appropriate amendment based on a 1994 committee proposal was incorporated into the Act in 1996.

In 1973, the Finnish Museums Asso- ciation launched an active campaign for basic university education in museumrelated subjects. As requested by the National Council for Higher Education, the museology working group of the Association prepared a proposal for a basic study programme in museology in 1982. The University of Jyväskylä introduced degree studies in museology as of autumn 1983, followed by similar programmes in Turku, Oulu and Helsinki. The post of senior assistant in museology established at the University of Jyväskylä in 1989 was converted into a professorship in 1998. Future restorers have been able to study at college level since 1984.

1986 saw the adoption of the Act and Decree concerning state guarantees for exhibitions, as proposed by a working group at the Ministry of Education. This reduced the financial risks faced by museums importing exhibits from other countries. The copyright provisions concerning various works of art were incorporated into the new Copyright Act, adopted in 1995 after a protracted preparatory process. It also harmonized Finnish provisions with EU legislation. Nevertheless, the new provisions are complex and pose problems for museums if strictly adhered to.

Quite a few important pieces of legislation concerning Finland's cultural heritage were thus put into effect in the period between the 1970s and '90s. They also provided museums with better general conditions for their operations. The Finnish Museums Association had long campaigned for the improvements gained with the passing of these new laws, and, in fact, many of them had been its long-term goals. The most important were the 
Government decision creating the system of regional museums in the early 1980s, the eventual adoption of the Act concerning state subsidies for museums in 1988, and above all the new Museums Act in 1992, which extended state subsidies to all museums with professional staff. The aims incorporated into the Government decision and the Museums Act were first outlined during the Association's early years, but were not formulated until after the publication of the 1965 report by the Museum Act Committee appointed by the Association in 1962. The Association is extremely happy with the new system; after all, the principles that it embodies are very similar to the proposals put forward by its Museum Act Committee.

The new rules approved in 1991 enabled the Finnish Museums Association to adopt a new working culture, the most visible manifestation being the election of the Chairman by the Annual Meeting. Until then, the Chairman had been chosen by the Governing Board. The changes showed that the Association had become an open organization serving an important national function through the museums that are its corporate members. In 1971, the Museum Symposiums that had earlier been held in specific years became annual events (the 45th Symposium took place in 1998). The first Art Museum Symposium, organized by the National Gallery, was held in 1953 and the first Symposiums for the Museums of Technology and Natural History in 1974. The Association has been involved in organizing the Symposiums for the Museums of Technology from the very start, and assumed responsibility for the Art Museum Symposiums and the Symposiums of
Natural History Museums in 1981 and 1992, respectively. Thus, there are now four different Symposiums, though only two - the National Museum Symposiums and Art Museum Symposiums - are held every year.

In the 1960s, the Association assumed a new role as a state advisory body and was asked to submit official opinions, memorandums and letters, and invited to official hearings, etc. In giving opinions and putting forward initiatives, the Association has been able to promote its own aims concerning the running and development of museums. A number of working groups, headed by a board member, to which staff from different museums and other experts were invited were set up to deal with the Association's separate projects. The results of these working groups' deliberations were often made available as recommendations or in the Association's own publications.

The Association faced its only serious crisis in connection with the 1972 NBA reorganization. In the spring of 1974 , the party representing the Communists and left-wing Socialists launched a parliamentary initiative aimed at making the NBA the sole manager of state-subsidized museum matters in Finland. This would have made the Association ineligible for State grants and, consequently, put its future at risk. The Ministry of Education, however, was of the opinion that the Association performed an important function and should thus be granted support.

The influx of competent museum officials continued in the 1970s. Of the 607 respondents in the Association's 1991 survey, 107 had entered the field in 19761980,129 in 1981-1985 and 136 in 
30 1986-1990. In 1997, Finnish museums had a total of 1288 permanent employees, half of whom had professional qualifications. The new situation forced the Association to revamp its training programmes. In contrast to the earlier curators who were content with 'basic training', museum staff with research degrees had to be provided with supplementary training that took into account the new social challenges. The Association's Training Officer appointed in 1980 has proved an excellent investment: in 1979 there were two training courses with 158 participants, while the 39 courses held in 1997 attracted 1133 participants.

Professionalization changed the museum community, which had formerly consisted of museum curators and other enthusiasts. The Association's publications and meetings contributed significantly to this development. The themes discussed at Museum Symposiums and the topics dealt with the various training courses are a fair indication of the speed with which technological and intellectual innovations have been gaining ground in the museum field.

The collections of local museums were inventoried by the 13 provincial museums between 1967 and1976. The project was funded by the Ministry of Education and coordinated by the Finnish Museums Association. Almost 100,000 objects were catalogued and 110,000 photos taken during the project! Similarly, in 19971998, the Association coordinated allocation of the Myytti (Myth) project funds to museums. This money, granted by the Ministry of Education, was intended for launching a project under which information on one of Finland's national treasures, the 36 million objects in Finnish museums, is to be converted into digital form and the necessary complementary training provided.

The articles in the Osma yearbooks and the publications brought out in connection with Museum Symposiums have provided those in the museum field with useful work-related information. In 1972, the Association published a guide to protection against burglary (intended for museum staff only), and the first publicly available museographic work, a guide to preserving and keeping museum objects, appeared as the Association's 13th publication in the same year. By 1998, nine additional publications on the same theme had been issued. Since the 1940s, the Association has also made efforts to promote interaction between museums and schools. In 1980, it compiled a survey on this subject, and the following year, appointed a working group to plan new forms of cooperation between museums and schools. The 1982 National Museum Symposium, with its focus on museums complementing school education, and the Symposium publications, brought the matter to public notice. The year 1986 saw the publication of the book Opintokäynti museoon (Study trips to museums), a result of collaboration between the Association's working group and the National Board of General Education.

The large number of new museums and museum officials required new communicative resources, so the Association started publishing an annual Soitetaan museoon (Let's Call the Museum) directory in 1986. The following year saw the launch of the Julius information bulletin.

Rapid developments in communication technology in the 1980s and '90s opened up new prospects. English versions of the 
museum directories were published in 1973 and 1990, and since 1987 the journal Museo has had English summaries of its most important articles. Nevertheless, the language barrier remained more or less unbroken until 1996, when the Association opened its English-language website (http://www.museoliitto.fi) which provides links and up-to-date information about Finnish museums.

\section{THE ASSOCIATION'S THREE ERAS}

Division of the 75-year history of the Finnish Museums Association into three equal parts produces the following result: 1923-1947, 1948-1973 and 1974-1998. Solveig Sjöberg-Pietarinen distinguishes three museum generations: collectors, organizers and communicators. They do not appear simultaneously; like a family, each museum has its own history. Knut Drake has divided museum staff into four successive generations: scientifically-oriented old gentlemen (1890-1930), staff with a multitude of skills and high working ethic (1930-1960), specialized professionals (1960-1990) and communicators in the service of society (since 1990).

The Association was established for museums run by collectors and organizers, so that the NBA could raise standards at local museums. At that time, the generation of old gentlemen was in decline. The next generation, staff with a multitude of skills, was already emerging, and until the 1960s, their views were disseminated by the Association in the form of advice, grants and training, and at Museum Symposiums.

The periods 1947-1948 and 1972-1973 coincided with important changes in the
Association's operational approach. In 1946, the Association acquired a full-time museum adviser, which was one reason why it was able to distance itself from the NBA. The last year the Association granted funds to museums was 1974 which marks the end of 47 years of financial assistance to local museums. The professionals and communicators working at local authority museums did not need advice, but a common approach to ways of watching over their interests, standardization, provision of information and complementary training. An Information Officer and Training Officer (since 1972 and 1980 , respectively) were appointed to serve these needs. Time will tell whether 1998 was also a year of change.

As its name suggests, the Finnish Museums Association was established to serve the interests of the museums. The number of corporate members has grown as follows:

$\begin{array}{cc}\text { Year } & \text { Corporate members } \\ 1923 & 24 \\ 1933 & 47 \\ 1943 & 66 \\ 1953 & 77 \\ 1963 & 107 \\ 1973 & 163 \\ 1983 & 187 \\ 1993 & 176\end{array}$

It should be remembered, however, that as more and more museums were transferred to the control of local authorities in the 1960 s, the local authority itself with its several museums became the member, instead of the individual museums themselves. In other words, until the late 1960 s, the number of corporate members correlated with the number of museums 
32 involved in Association activities; since the 1970s, however, the number of corporate members has been smaller than the number of museums in the Association.

One indication of the importance the nation attaches to the Association is the amount of funding it receives from the state. In 1927, after Julius Ailio had been appointed the Minister of Education, the Association was finally granted the financial assistance it needed to implement its declared aims. As Minister of Education, Julius Ailio was able to reach an understanding with Julius Ailio, Chairman of the Finnish Museums Association, whereby the Minister of Education provided the Association with the necessary funds. From 1927 to 1997, the Association's state subsidies and available funding totalled the following (FIM 1 = 5.975 euros; 1999):

$\begin{array}{ccc}\text { State subsidies } & \text { (FIM 1996) Available funds (FIM 1996) } \\ 1927 & 154,660 & 185,783 \\ 1937 & 201,875 & 431,708 \\ 1947 & 119,082 & 227,301 \\ 1957 & 464,000 & 649,958 \\ 1967 & 1,288,800 & 2,651,398 \\ 1977 & 979,195 & 1,404,257 \\ 1987 & 1,303,400 & 2,714,470 \\ 1997 & 1,679,500^{*} & 3,096,529^{*}\end{array}$

* 1997 sums have not been converted into 1996 FIM

The funds granted to the Association by the Government were originally intended for local museums. As state lottery money began to be earmarked for this purpose in the 1950s, the Association's financial assistance to local museums became less important. There was a significant rise in state subsidies as the 50th anniversary of Finland's independence in 1967 approached. This enabled the Association to make a sizeable contribution to the celebrations in the form of the largest touring exhibition of the day. After that peak, state subsidies remained unchanged until a new rise in 1996. This was partly due to the Ministry of Education programme 'Finland's way to the information society', in which the Association has a number of training functions.

The amount of money the Association can spend every year provides the framework for its activities. In addition to state subsidies, the Association has also had other sources of income. In the 1930s and '50s, lotteries played a major role, and since the 1970s, the Association has been able to raise funds by selling its own products and services. The expansion of activities in the post-war period is partly explained by the rapid growth in resources.

The Finnish Museums Association has always been quick to react to changes in its environment, and its operations and funding are based on an indigenous model taking into account the interests of local authorities, private associations and foundations.

The article is a summary of the author's book 75 vuotta museoiden hyväksi - Suomen museoliitto 1923-1998. The 235-page book is the 45th publication of the Finnish Museums Association.

Janne Vilkuna works at the University of Jyväskylä as Professor of Museology. He is also a member of the editorial staff of Nordisk Museologi and its Finnish contributor.

Adr. University of Jyväskylä, Museology,

P.O.Box 35(A), FIN-40351 Jyväskylä

Fax: $+358-14601461$

Email: jvilkuna@campus.jyu.fi 